\title{
Uma missão, uma revista que nos orgulha
}

Rev Port Imunoalergologia 20I9;27 (4):277

Luís Miguel Borrego

\section{Caros Colegas,}

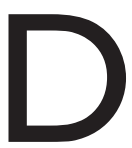
irijo-vos estas últimas palavras como Editor da Revista Portuguesa de Imunoalergologia (RPIA), função que desempenhei com um enorme prazer, acompanhado de uma fantástica equipa do Conselho Redatorial e de redatores de excelência.

Agradeço a colaboração dos vários colegas que efetuaram as revisões científicas dos trabalhos que nos foram submetidos para publicação e que contribuíram para a qualidade das publicações, bem como de todos os que participaram na rúbrica dos artigos comentados e na secção das notícias.

Agradeço ainda a todos os autores que nos confiaram os seus trabalhos para publicação e que tornam viva a nossa RPIA.

Durante este mandato foi possível manter um elevado grau científico em todas as publicações da RPIA, tendo sido concebida a rubrica de Casos Clínicos sob a forma de Allergy Immage, onde se pretende a descrição sumária de um caso clínico acompanhada de uma foto. De igual modo foi criada uma secção para a publicação de protocolos clínicos de aplicabilidade diária. Preten- deu-se desta forma que a RPIA tivesse um papel didático e formativo. Por fim, a secção de colaboração com a ASBAI pretende promover o intercâmbio de colegas imunoalergologistas brasileiros e portugueses, na publicação de artigos de trabalhos realizados no Brasil.

De modo a promover a publicação na RPIA foram criados os prémios de melhor artigo original e melhor artigo de revisão, de caráter anual, sendo os prémios atribuídos na Reunião Anual da Primavera da SPAIC.

Da minha parte, a minha colaboração estará sempre ao dispor da Sociedade Portuguesa de Alergologia e Imunologia Clínica (SPAIC) e da RPIA.

A Prof. Mariana Couto, que tem exercido brilhantemente funções como Secretária-Geral da RPIA, irá substituir-me no cargo de Editor, constituindo este facto desde já uma garantia de sucesso e dinamismo renovado à RPIA, desejando-lhe as maiores felicidades e êxito.

O meu muito obrigado a todos quantos colaboraram com a RPIA ao longo deste mandato. Que continuemos todos a orgulhar-nos da nossa revista!

Luís Miguel Borrego

Editor da RPIA 